\title{
« Daftar-e ḥosn. Barresī-ye namādegān-e ḥorūf dar vașf-e jamāl-e čehre dar adab-e fārsī ». Hìyāl (Khiyal), 4 (1382/2003), pp. 24-47.
}

\section{Charles-Henri de Fouchécour}

\section{(2) OpenEdition \\ 1 Journals}

Édition électronique

URL : http://journals.openedition.org/abstractairanica/2000

ISSN : 1961-960X

Éditeur :

CNRS (UMR 7528 Mondes iraniens et indiens), Éditions de l'IFRI

Édition imprimée

Date de publication : 15 mai 2005

ISSN : 0240-8910

Référence électronique

Charles-Henri de Fouchécour, « « Daftar-e hosn. Barresī-ye namādegān-e horūf dar vașf-e jamāl-e čehre dar adab-e fārsī ». Hiyāl (Khiyal), 4 (1382/2003), pp. 24-47. », Abstracta Iranica [En ligne], Volume 26 | 2005, document 371, mis en ligne le 07 décembre 2005, consulté le 25 septembre 2020. URL : http://journals.openedition.org/abstractairanica/2000

Ce document a été généré automatiquement le 25 septembre 2020.

Tous droits réservés 


\title{
« Daftar-e ḥosn. Barresī-ye
} namādegān-e horūf dar vașf-e jamāl-e čehre dar adab-e fārsī ». Hiyāl (Khiyal), 4 (1382/2003),

\author{
pp. 24-47.
}

\author{
Charles-Henri de Fouchécour
}

L'A. engage son enquête sur la description de la beauté du visage humain en littérature persane, à partir de la symbolique des lettres. Car, pour une part non négligeable, certaines lettres de l'alphabet arabe ont servi de comparant dans cette description par comparaison. Bahman Nāmvar Moṭlaq rappelle avec justesse que l'art islamique fait suite à la croyance au pouvoir révélateur des lettres mêmes du Coran. Les lettres écrites sont belles, indépendamment de toute signification particulière, puisque l'univers est un livre écrit par le divin Créateur, et chacun de ses éléments en est une lettre. Ultimement, la beauté graphique des lettres tient sa beauté de la divine beauté. Cette beauté graphique a porté les poètes à y trouver ce qu'ils veulent dire de la beauté du visage, partie privilégiée du corps humain. L'enquête se poursuit avec un large choix bien fait d'exemples pris sur plusieurs siècles de littérature persane, où l'on voit comment des lettres arabes ont permis la description en question. On commence par le point, à partir duquel le calame trace un trait, fait de points, comme l'on sait. Le point du visage est le grain de beauté (Hăl), le trait est la fine barbe du jeune pubère (Hatț),

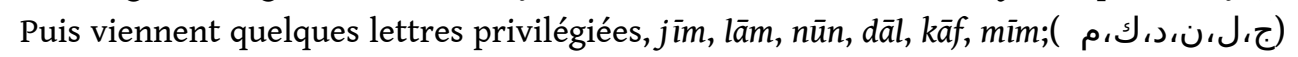
à elles sont comparées les autres parties du visage, et d'abord ce qui l'entoure, la chevelure, en désordre ou nouée en nattes. Par exemple, avec le grain de beauté, la mèche forme un superbe jīm (voir țāfeẓ, Dìvān, 38, 3). Avec la bouche, les lèvres, les yeux, etc., l'on a affaire à des comparaisons plus élaborées, où l'on a recours aussi au calame, à l'encre, à la page coloriée, pour affiner les comparaisons. Ainsi la beauté des 
lettres superbement calligraphiées offre un accès à la beauté intérieure au visage, où se lit quelque chose de la divine écriture.

INDEX

Thèmes : 11.1.1. Littérature persane classique

nompropre Ḥāfez, Hāfez

\section{AUTEURS}

CHARLES-HENRI DE FOUCHÉCOUR

Fondateur de la revue Abstracta Iranica - Paris 